\title{
DESCRIPTION AND EVALUATION REGARDING THE HOLY MYSTERY OF PRIESTHOOD IN ROMAN CATHOLICISM
}

\author{
Assoc. Professor Phd. Dragoș Corneliu BĂLAN, \\ Faculty of Orthodox Theology, "Ovidius" University of Constanta, \\ ROMANIA \\ E-mail: dragos_balan1980@yahoo.com
}

\begin{abstract}
The central difference between the Orthodox teaching and the Catholic one regarding the Church comes from the conception regarding its foundation. In the Catholic conception, the visible Church was founded before the Pentecost, on the testimony of Saint Peter the Apostle, and at Pentecost only the invisible Church would have been added. The entire conception about the hierarchy, in the Roman Catholic Church, is strictly juridical. In reality, as the Orthodox theology testifies, the essence of the ecclesial hierarchy is charismatic, not juridical. This is what the great difference to the Catholic teaching consists in. The Eastern theology makes no abstraction of jurisdiction and canon law, yet, jurisdiction depends on grace, not grace on jurisdiction, contrary to what some Western Church theologians would suggest in certain works such as those belonging to the Western Theology.
\end{abstract}

Keywords: celibacy; pope, priesthood, bishop; hierarchy;

\section{INTRODUCTION}

The Roman-Catholic theology has a special conception of the nature of the priesthood mission. It considers that the mission to teach, sanctify and lead the people on the way of salvation goes, in various degrees, to the entire Church, starting with the pope and ending with the last member of the Catholic laity.

"The Church, says the Decree on the Laity's Apostleship, Apostolicum actuositatem, was born so that, spreading on the whole earth Christ's Kingdom for the glory of God the Father, She may make all the people partakers to the saving redemption and by them, the whole world may be submitted to Christ into the truth. All the activity of the Mystic Body turned towards this goal is called apostleship; the Church exerts it through all her limbs, certainly, in different ways: because the Christian calling is, by its nature, also a calling to apostleship... Thus, on all Christians is imposed the noble task of working all the time for the divine news of salvation to be known and received by all the people, on the whole earth."

The difference between services is just one of rank and extent. In other words, the pope exerts this mission on the level of the whole Church, the bishops, in their bishoprics, the priests in parishes, and the laypeople each in the extent of his area of action ${ }^{2}$. Consequently, the Catholic theology does not distinguish, like the Orthodox, between special

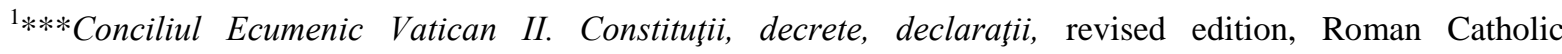
Archdiocese, Bucuresti, 2000, pp. 246-247.

2 ****Conciliul Ecumenic Vatican II. Constituţii, decrete, declaraţii, pp. 246-247. 
or ordination priesthood and the general priesthood of God's people; in the Catholic vision there is but one priesthood, the special one, yet distributed gradually depending on the Church level each priest is on. The pope holds the fullness of this priesthood; the bishops hold the same priesthood, yet at the lower degree according to the level they occupy; the priests' power derives from that of the bishops, and, finally, the laypeople participate at the lowest level in this grace-filled priesthood, exerting it where it cannot be exerted, at their level, by the priests. All participate, however, to the same apostleship.

\section{CHURCH PRIESTHOOD IN THE ROMAN CATHOLIC DOCTRINE}

The central difference between the Orthodox teaching and the Catholic one regarding the Church comes from the conception regarding its foundation. In the Catholic conception, the visible Church was founded before the Pentecost, on the testimony of Saint Peter the Apostle, while at Pentecost only the invisible Church would have been added. From here, a natural gap followed between the visible or juridical Church and the invisible or spiritual one. The entire conception about the hierarchy, in the Roman Catholic Church, is strictly juridical $^{3}$. In reality, as Orthodox theology testifies, the essence of the ecclesial hierarchy is charismatic, not juridical.

This is what the great difference to the Catholic teaching consists in. The Eastern theology makes no abstraction of jurisdiction and canon law, yet, jurisdiction depends on grace, not grace on the jurisdiction, contrary to what some Western Church theologians would suggest in certain works such as those belonging to the Western Theology. ${ }^{4}$

A part of the Catholic theology strongly emphasized the visible, institutional element of the Church. The invisible elements remained only implied. According to this part of Catholic theology, the church has a character of historical, authoritative, external society. Lately, however, the Catholic theologians have tried to underline and highlight the theandric reality of the Church, instead of the administrative centralism. In many formulations, these theologians meet and are one with the Orthodox ones. but, unfortunately, there remains a separation between God and the Church; it remains closed within historical limits, in the order of the created, because the grace in it remains a created grace. I'd rather say: Yet an aspect of the Church still needing clarification is that of the grace, as it still has to dawn on all theology: God's grace is only uncreated.

\section{a) Pope's role concerning the Church; Pope - "foundation of the unity of the faith"}

Whereas in the Orthodox Church all the bishops are equal according to their divine right power, each bishop being the center of the spiritual power in an eparchy, and reunited together, in an ecumenical council, they constitute the infallible organ of the Church, in Catholicism, there used to be a tendency to see, as concentrated in the pope, all the power on earth, both lay and spiritual. During the last centuries, the pope gradually came to be seen as having lost his worldly power, yet concentrating in himself, increasingly more, the spiritual one . $^{5}$

\footnotetext{
${ }^{3}$ George Remete, Dogmatica Ortodoxă, textbook for Theological Seminaries, 3rd edition, Publishing House Reîntregirea, Alba-Iulia, 2000, p. 301.

4 Ferdinand Klostermann, "Rolul credincioșilor în Biserică după Conciliul al II-lea Vatican", in Studii Teologice, 26/ 3-4 (1973), p. 57.

${ }^{5}$ N. Chițescu, Isidor Todoran, I. Petreuță, Teologia Dogmatică și Simbolică, textbook for the Faculties of Theology, vol. II, Editura Institutului Biblic și de Misiune al Bisericii Ortodoxe Române, București, 1958, p. 182.
} 
The Council of Trent (1545-1563) was the one that considered it right to grant to the pope a supreme power in the whole Church, giving him the right to confirm the bishops. The Tridentine Synod calls the pope "a descendant of the Apostle Peter, the coryphaeus of the Apostles" and "the representative of Jesus Christ," and the Roman Catechism states that "the invisible Guide and Ruler of the Church is Christ, which holds the throne of Rome" .

The First Vatican Synod (1869-1870) declares that when the pope speaks excathedra, he enjoys that infallibility with which the holly redeeming wanted His Church to be endowed in defining the teaching of faith or morals, so the definitions of the Roman pontiff are unchangeable to itself (ex sese), and not by the consensus of the Church ${ }^{7}$.

Finally, the Second Vatican Council (1962-1965) speaks of the pope, in terms of his role in relation to the Church, no more and no less than that he is "the perpetual and visible principle and foundation of the unity of faith and communion"s.

Therefore, the Second Vatican Council distinguishes the pope from the assembly of the whole episcopate and even from the whole Church: the pope has the power to teach the people, but he has it in the special form of the infallible magisterium; the pope has the power to lead the same people, but he has it in terms of a sacred primacy?

The acts of the Second Vatican Council aimed at consolidating the papal position in the Roman Catholic Church. The pope's quality of "foundation of unity in faith" is based entirely on the separation between Christ and the Holy Spirit, a consequence of the Filioque addition. Due to the separation between Christ and the Holy Spirit, the divine Revelation is transformed into a formal deposit, which loses its connection with Christ and the community of believers, in order to be made dependent, above all, on the papacy. This is one of the reasons why the Second Vatican Council, changing the relationship between faith and the pope, considers the pope as the foundation of the faith. ${ }^{10}$

Also by virtue of the separation between the Holy Spirit and Christ, the Council, seeing in the Holy Spirit an impersonal power, on which the charism of papal infallibility is based, declares that, since the assistance of the Holy Spirit was promised to Peter, "the pope alone has the charism of infallibility of the Church" ". Because infallibility would have according to Catholic theology - the guarantee of the assistance of the Holy Spirit, and the Holy Spirit works separately from Christ, the papacy makes total abstraction from Christ, that is, it is totally independent of Christ.

It could thus be stated by Roman Catholics that "in the light of the Holy Spirit, the pope enlightens the faith, removing from the treasury of Revelation old and new things" and that "the Church does not remove from Holy Scripture only its certainty on the points of Revelation" $"$. We deduce that the pope has the possibility of declaring as infallible truths

\footnotetext{
${ }^{6}$ Ion Bria, Tratat de Teologie Dogmatică și Ecumenică, Publishing House România Creștină, București, 1999, p. 165.

${ }^{7}$ Vasile Citirigă, Probleme fundamentale ale teologiei dogmatice şi simbolice, course notes, vol. II, Publishing House Ex Ponto, Constanța, 2001, p. 148.

${ }^{8}$ Dumitru Popescu, Ortodoxie și contemporaneitate, Editura Institutului Biblic și de Misiune al Bisericii Ortodoxe Române, București, 1996, p. 67.

${ }_{9}$ Paul Evdokimov, Ortodoxia, translated by Irineu Ioan Popa, Editura Institutului Biblic şi de Misiune al Bisericii Ortodoxe Române, București, 1996, p. 178.

${ }^{10}$ Dumitru Popescu, Teologie și cultură, Editura Diogene, București, 1993, p. 37.

${ }^{11}$ Mihai Enache, „Poziția Bisericii Ortodoxe în problema dialogului și a intercomuniunii în Biserica RomanoCatolică”, în Studii Teologice, 27/1-2 (1975), p. 41.

${ }^{12}$ Dumitru Popescu, Teologie și cultură, p. 68.
} 
without biblical grounds and of introducing into the revealed deposit truths which have not been formally revealed by Christ.

Due to infallibility, the papacy subdues both the bishop and the pastored people, concentrating, in his person, the whole Church. This is because the infallibility of the Church resides in the episcopal body only when it exercises the supreme magisterium together with the pope, and the people cannot exercise their right to express themselves validly by "unanimous consensus", but must respect as infallible the truths of faith and morals defined by the pope.

In the Orthodox Church, the collective form of community preservation of the truth, as the care of the sacramental and royal priesthood, is that of receiving the decisions of the synods. "The guardian of godliness and faith is the whole people of the Church" - says the Encyclical of Eastern Patriarchs from $1848^{13}$. This document says that "with us, innovations could not be introduced by patriarchs or synods, because in our country the safeguarding of religion resides in the whole body of the Church, that is, in the people themselves, who want to keep the faith intact"14.

\section{b) "Tu es Petrus..."}

„And Jesus answered and said unto him, Blessed art thou, Simon Bar-Jonah: for flesh and blood hath not revealed it unto thee, but my Father which is in heaven. And I say unto you, that Ye are Peter, and upon this rock, I will build my church; and the gates of hell shall not prevail against it. And I will give unto thee the keys of the kingdom of heaven: and whatsoever thou shalt bind on earth shall be bound in heaven: and whatsoever thou shalt loose on earth shall be loosed in heaven." (Mathew 16, 17-19).

In the New Testament writings, the tradition regarding the prominent position of the Apostle Peter in the early Church and the circle of the other Apostles is evident. This primacy of St. Peter was also recognized by the Holy Apostle Paul, as was later recognized the primacy of St. James - the brother of the Lord ${ }^{15}$ - in the community of Jerusalem. Indeed, it is known that the old Christian tradition has preserved the image of St. Peter in a fairly extensive way, especially because, after St. Peter, Jacob - the Lord's brother, soon followed the leadership of the Church in Jerusalem. It is a succession that took place after the imprisonment of the Apostle Peter, by order of Herod Agrippa, in 44 AD, in connection with the beheading of Jacob, son of Zebedee, and the face of death threats against St. Peter. (cf. Acts 12, 1-7).

The Holy Apostle Peter seems to have left the city of Jerusalem under these circumstances (cf. Acts 12:17), probably heading for Antioch. Without exercising a leading position, St. Peter enjoyed, until his death, the prestige of a particular authority, which was later verified by the proto-Christian traditions that tried to re-evaluate his personality. ${ }^{16}$

In the period following the death of the Apostle Peter, when the issue of maintaining the Church on the line of his teachings received from the Lord was raised, St. Peter became the symbol of the unity of the whole Church. ${ }^{17}$

\footnotetext{
${ }^{13}$ Vasile Citirigă, Probleme fundamentale ale teologiei dogmatice și simbolice, p. 149.

${ }^{14}$ Vasile Citirigă, Probleme fundamentale ale teologiei dogmatice şi simbolice, p. 149.

15 Alexandru Joița, „Aspecte actuale în ecleziologia ortodoxă și cea romano-catolică”, în Studii Teologice, 33/5-6 (1981), p. 78.

${ }^{16}$ Constantin Preda, „Tu es Petrus...”: Matei 16, 17-19, în Studii Teologice, 1/2 (2005), p. 56.

17 W. Pannenberg, „Riflessioni evangeliche sul servizio petrino del vescovo di Roma”, in Anali di Scienze Religioase, 2 (1997), p. 116.
} 
The image of the Holy Apostle Peter in the New Testament is, therefore, the expression of the requirement of a ministry that guarantees the unity of the Church in its entirety and is not understood as the exercise of a jurisdiction related to a function of power (potestas) but of an authority related to his person which must be remembered that auctoritas is determined by conviction and credibility.

There is, in the promise of St. Peter, however, a resemblance to the story in Genesis 17, 1-8, in which Abram, for his faith, received another name, Abraham, with the promise of becoming the ancestor of many peoples. God says to him, "And this is My covenant with you: You shall be the father of many nations, and you shall no longer be called Abram, but Abraham shall be your name, for I will make you the father of many nations" (Genesis 17, 45). The change of name indicates the new role that God has given him, making him the ancestor and father of a multitude of peoples. ${ }^{18}$

Like Abraham, the Holy Apostle Paul occupies a special place in the history of salvation: he is the first of the believers of the messianic age, he is the "father" of a new people "cut" by God not from a rock or a stone quarry (Abraham and Sarah), but constituted by God Himself on the stone of the confession of the Apostle Peter. The text in Matthew 16: 17-19 is the fulfillment of the prophecy made by St. John the Baptist: "You shall not believe that you can say for yourselves: Our father is Abraham, cause I tell you that God is able to raise sons (in Hebrew - "banim") even from these rocks (in Hebrew - "abanim") to Abraham" (Mathew 3, 9).

This stone or foundation on which the Roman Catholics claim that the Church is built gives the pope a special significance: he is the substitute of Christ on earth, the Vicar of Christ! ${ }^{19}$ The Pope takes the place of Christ, acting in the person of Christ! These statements lead to the idea that, in the view of Catholic theology, the papacy is indeed the highest degree of actualization of the presence of Christ in the Church, the highest form under which Christ Himself appears in the world.

In the Western Church, the pope is more than the entire synod of bishops in the Orthodox Church. In the East, the decisions of a synod, even if it was considered ecumenical, have no value unless they are subsequently appropriated by the whole Church. Therefore, paraphrasing the theologian Hristu Andrutsos, only this subsequent approval of the Church reveals whether the synod was ecumenical, constituting the external criterion of the ecumenical synod. ${ }^{20}$ The Church can contradict or reform the decisions of a synod that has, at one time, gathered the largest number of bishops. In the West, this is not the case. The pope's views can no longer be changed by anyone. They do not become irreformable through the subsequent consent of the Church, but have this power from the pope.

And for the Orthodox, the episcopate has the magisterium of teaching and infallibility by ordination, not by a special delegation from the faithful. But provided he exercises it in accordance with the Church. ${ }^{21}$

When he does not fulfill this condition, he is wrong. The church always bears witness to the truth of the teaching preached or formulated by the episcopate, and it must be constantly in accord with the spirit within it, with the atmosphere within it, in its teaching activity. It is analogous to the relationship between father and family. The father represents

\footnotetext{
${ }^{18}$ Constantin Preda, ,Tu es Petrus...”: Matei 16, 17-19, p. 58.

$19 * * *$ Conciliul Ecumenic Vatican II. Constituţii, decrete, declaraţii, p. 78.

20 Hristu Andrutsos, Dogmatica Bisericii Ortodoxe Răsăritene, Trans Dumitru Stăniloae, Editura Arhiepiscopiei Diecezane, Sibiu, 1930, p. 110.

${ }^{21}$ Hristu Andrutsos, Dogmatica Bisericii Ortodoxe Răsăritene, p. 110.
} 
the family based on this quality that he received through the marriage certificate, not through a special delegation from the family members, ${ }^{22}$ but he speaks and must always speak in accordance with the interests of the family, tradition, and a certain spirit of it. . In this sense, the infallibility is of the whole Church and the whole contributes to the infallible support and formulation of the teaching, although the episcopate is the ordinary organ of its articulated expression $^{23}$.

According to Roman Catholic doctrine, however, "the subject of infallibility is the Church of the Teacher" exclusively, which "consists of bishops" ${ }^{24}$, or, more precisely, the pope, without any participation of the Church, not even by consent (ex sese ex consensu Ecclesiae).

The Second Vatican Council did not link the infallibility of the pope to any condition, except for the vague and much-discussed term of the ex-cathedra. It did not link it to the pope's agreement with the Church, on the contrary, it excluded this condition, it did not link it to the agreement with Tradition, which made Pope Pius IX declare "Io sono la Tradizione" ${ }^{, 25}$.

\section{c) The Celibacy of Priests}

The Orthodox Church does not consider conjugal life contrary to the Priesthood, but priests who want to live in marriage must marry before ordination, and the second marriage cannot be contracted, according to the words of the Holy Apostle Paul - who says that the priest must be " man of one woman" (I Timothy 3, 2 and Titus 1,6) - and of the old church traditions.

Moreover, in the old Church, celibacy is not imposed even on bishops. Hilary of Pictavia and Gregory of Nyssa were married. But at the Synod of Trullan, in 692, he declared in Canons 12 and 13 that bishops should not be married, not out of contempt for marriage, but so that they could devote themselves entirely to the leadership of the Church. ${ }^{26}$

The Roman Catholic Church, especially from Pope Gregory VII (1073), forbids marriage of all clerical ranks to the subdeacon/hypodeacon. This is in line with the tendency of the Catholic Church to raise the clergy above the laity, as a strong and independent class. The celibacy of priests was imposed in the $\mathrm{West}^{27}$ by the Synod of Elvira (Spain), in 306, to make priests a true army, always at the disposal of the pope and the Church, a ,militia Christi" $^{28}$.

The Orthodox Church remained faithful to the decision of the First Ecumenical Council, which allowed the marriage of the clergy, even bishops. Only after the Fourth Ecumenical Council was the celibacy of bishops imposed.

\footnotetext{
${ }^{22}$ Hristu Andrutsos, Dogmatica Bisericii Ortodoxe Răsăritene, p. 110.

${ }^{23}$ N. Chițescu, Isidor Todoran, I. Petreuță, Teologia Dogmatică și Simbolică, p. 184.

${ }^{24}$ Vasile Suciu, Teologia Dogmatică fundamentală, vol. II, f.e., Blaj, 1927, p. 47.

25 John Meyendorff, Ortodoxie și catolicitate, translated by Călin Popescu, Publishing House Sophia, București, 2003, p. 68.

${ }^{26}$ Ioan N. Floca, Canoanele Bisericii Ortodoxe - texte și comentarii, f.e., Sibiu, 1992, p. 211.

${ }^{27}$ Nicuşor Tucă, Valențe teologice în Liturghie și Sfintele Taine, Editura Arhiepiscopiei Tomisului, Constanţa, 2014, p. 177.

${ }^{28}$ Dumitru Ichim, „Problema celibatului preoțesc în Biserica Romano-Catolică”, în Studii Teologice, 22/9-10 (1970), p. 51.
} 


\section{ORTHODOX DOGMATIC EVALUATION OF THE PRIESTHOOD OF THE CHURCH REGARDING THE ROMAN CATHOLIC DOCTRINE}

Christ works on the faithful, through His threefold ministry, because of the role of mediator that the Priesthood has in the life of His Church. ${ }^{29}$ The important role of the ministering priesthood is that man cannot enter by himself into an endless loving relationship with God not only by the unseen way but also by the seen one, because of the priest, who is the visible sign of Christ's unseen presence in the Church. Of course, believers may personally offer certain prayers and sacrifices to God without the intercession of the ministering priesthood, but the sacrifices offered to Christ by the whole community are no longer subjectively brought by believers, as a general priesthood, but through the sanctified minister for this purpose, objectively. Believers always need the visible priest, especially them, because they need Christ as Mediator. "The priest symbolizes Christ as Mediator, symbolizes the fact that man cannot enter by himself into the endless loving relationship with God"30, says father Stăniloae.

The whole life of the early Church was led by the Holy Apostles, who cared both for the souls of the new converts and for their material situation, for they sold their possessions and brought the price of those sold and placed it at the feet of the Apostles, who distributed it to each, as needed (cf. Acts 4, 34-35) .

But as the number of the baptized increased, the Holy Apostles were obliged to entrust the service at the table to other worthy men, chosen from among the disciples, seven in number, who would be "of good name, full of the Holy Spirit and wisdom," and when they were found, they placed them before the Apostles, who, praying, "laid their hands on them" (cf. Acts 6: 1-6). These elected men, called deacons, constitute the first step of the Church hierarchy, from their election and establishment, we see what the qualities were, that is, by the laying on of hands - ordination. Although in the invisible aspect the Church is led by the Savior Christ, still, in the visible aspect, the community of believers is led by the church hierarchy. ${ }^{32}$

We know that the Savior first chose twelve Apostles (Matthew 10: 1-4; Luke 6: 1217) to perform the Holy Sacraments and to lead believers to holiness and salvation. Although they were chosen by the Savior and endowed with the grace of the Holy Spirit, they were not immortal. Therefore, the Holy Apostles ordained, by the laying on of hands, followers to continue in the Church their threefold mission: to preach the Holy Gospel, to administer the Holy Sacraments, and to lead the faithful to salvation. Those chosen for this mission had to be endowed with special qualities because this service is holy and very important. ${ }^{33}$

The Holy Apostle Paul, addressing the bishops and priests of the parts of Ephesus, draws their attention to their great responsibility, saying, "Remember yourselves and all the flock over which the Holy Spirit has made you bishops, to preserve God's church, who won it with His own Blood" (Acts 20:28). The establishment of the hierarchy, in all its stages, is a Holy Sacrament, and those who are sanctified in it must fulfill special virtues ${ }^{34}$.

\footnotetext{
${ }^{29}$ Ionuț Chircalan, Creator și creație. Părintele Dumitru Stăniloae - valorificator al scrierilor areopagitice, Editura Universitară, București, 2021, p. 238.

${ }^{30}$ Dumitru Stăniloae, Teologia Dogmatică Ortodoxă, vol. II, Editura Institutului Biblic și de Misiune al Bisericii Ortodoxe Române, București, 1978, p. 236.

${ }^{31}$ Boris Bobrinskoy, Taina Bisericii, Trans de Vasile Manea, Editura Reîntregirea, Alba-Iulia, 2004, p. 131.

${ }^{32}$ Dumitru Popescu, „Sfânta Taină a Preoției - ierarhia sacramentală după Sfânta Scriptură și Sfânta Tradiție. Preoția obștească”, în Ortodoxia, 40/1 (1989), p. 11.

${ }^{33}$ Gheorghe Banu, „Ierarhia bisericească” în Îndrumător bisericesc, Episcopia Buzăului, 1 (1982), p. 121.

${ }^{34}$ Alexandru Joița, ,Aspecte actuale în ecleziologia ortodoxă și cea romano-catolică”, p. 74.
} 
These virtues or qualities are also mentioned by the Saint Apostle Paul in the following words: "But it is fitting for the bishop to be blameless, a man of one woman, awake, good, decent, hospitable, eager to teach others, not drunk, unfamiliar to beat, not agonizing for ugly gain, gentle, peaceful, unloving of silver, good steward in his house [...], for if he does not know how to arrange his house, how he will take care of the church of God [...]. Let deacons also be devout, not speaking in two ways, not giving much wine, not greedy for wickedness [...] to be husbands of a woman, to govern well their houses and their children "(1Timothy 3, 2 -12).

In time, another condition was added to these conditions, required by the cultural development of mankind, namely training in special, theological schools, where the priest acquires a specialized and universal culture, deepening the teaching of Christ for himself and to teach others, conditions without which no one can be ordained ${ }^{35}$. This is, broadly speaking, the orthodox teaching about the church hierarchy. But because we have referred to the Catholic teaching on the priesthood and the church hierarchy, we will try to answer the dogmatic errors of the Western Church's teaching on this subject.

1. The classic text of Matthew 16:18: "You are Peter and on this stone I will build my Church", invoked by Catholics as an argument, does not refer to Peter's personal faith, but to the faith professed in the name of the Apostles, because we know that his faith proved hesitant and he was even admonished with the words: "Go behind me, Satan!" In fact, the Holy Apostle Paul shows that the Church is built "on the foundation of the apostles and prophets, the cornerstone being Jesus Christ" (Ephesians 2:20).

2. The New Testament shows no priority of St. Peter over the other Apostles. On the contrary, he is rebuked by the Savior and even by the new Apostle Paul in Antioch. If he had a primate, he would have had to preside over the Synod of Jerusalem, which took place in the year 50 . We know that this synod was presided over by St. James.

3. The papal primacy contradicts the Holy Scripture and the Holy Tradition, which shows us, unanimously, that Jesus Christ is the head of the Church until the end of the ages, present in it permanently and there is no allusion or intention to leave a vicar ${ }^{36}$.

4. The Catholic argument that St. Peter pastored a bishop in Rome for 20 years has no dogmatic value. There is no historical evidence in this regard and, even if it were, his pastorate as bishop of Rome does not justify the primacy of jurisdiction, but only an honorary primacy. (primatus honoris).

5. Papal infallibility is only a human claim, which seeks to boast of divine attributes. We know that only the Church, as the mysterious body of Christ, is and remains infallible, and the existence of heretical popes - like Liberius who was a Semi-Arian, and Honorius who was a Monothelite - contradicts papal infallibility. ${ }^{37}$

\section{CONCLUSION}

In the history of the Christian Church, always, those who became members of the church hierarchy were ordained either directly by the Holy Apostles or by their legitimate followers. He who has not done so cannot have the apostolic succession of the grace of ordination and is thus excluded from the church hierarchy, breaking away from the one Church of Christ, holy, catholic and apostolic.

\footnotetext{
${ }^{35}$ Gheorghe Banu, „Ierarhia bisericească”, p. 123.

${ }^{36}$ John Meyendorff, Ortodoxie și catolicitate, p. 85.

${ }^{37}$ John Meyendorff, Ortodoxie și catolicitate, p. 85.
} 
The granting of a hierarchical step is done gradually, from the bottom up; thus, no one can receive the rank of bishop unless he was first a deacon and then a priest, or no one can be a priest without first being a deacon. For the special activity he carries out, the church hierarchy, at all times has enjoyed a chosen honor.

Roman Catholics, however, especially through the Second Vatican Council, further strengthened the pope's position in the Church. On the other hand, the Council sought to identify the episcopate with Christ and to separate it from ordinary believers, arguing that there are ontological differences between believers and the episcopate. It must be said that even in the Orthodox Church the position of priest and bishop often seems privileged in the church community, especially if we remember that, in the priest, in the bishop, and in the episcopate, it is recognized by all, ie "officially", the church community (the parish, the diocese, the Church as a whole); however, the priest and the bishop represent the whole community, but not broken by the community, but as a kind of head, which has in organic union with itself the community. Thus, his seemingly privileged position keeps him connected to the community and does not allow the bishop or priest to stand outside the community or above it.

There are no ontological differences between the faithful people and the hierarchy, but only functional ones. In the Church, there can be no real communion unless equality is respected in honor of the members. Only if the Church is seen as a communion, following the model of the Holy Trinity, is the danger of falling into clericalism avoided, in which the hierarchy is above the faithful.

The unity through the communion of the Church given in the Holy Spirit is the foundation of the pope and not the reverse, the pope as the foundation of unity in communion. The church is built on the foundation of faith and the Holy Spirit, because only in this way does it remain built on Christ and centered in Christ. ${ }^{38}$

Orthodox ecclesiology is incompatible with the legal conception of authority and the delegation of powers of a sovereign legislator, because it gives due importance to the Trinity and their personal presence in the Church through uncreated energies, but also to the role of Christ the Savior as head of the Church and source of the priesthood in the Church, through the Holy Spirit.

\section{BIBLIOGRAPHY:}

[1] ${ }^{* * *}$ Conciliul Ecumenic Vatican II. Constituţii, decrete, declaraţii/The Second Vatican Ecumenical Council. Constitutions, decrees, declarations, revised edition, Arhiepiscopia Romano-Catolică, Bucureşti, 2000.

[2] Andrutsos, Hristu, Dogmatica Bisericii Ortodoxe Răsăritene/Dogmatics of the Eastern Orthodox Church, trad. de Dumitru Stăniloae, Editura Arhiepiscopiei Diecezane, Sibiu, 1930.

[3] Banu, Gheorghe, „Ierarhia bisericească”/"The church hierarchy” in Îndrumător bisericesc, Episcopia Buzăului, 1 (1982).

[4] Bobrinskoy, Boris, Taina Bisericii/The Mystery of the Church, translated Vasile Manea, Editura Reîntregirea, Alba-Iulia, 2004.

[5] Bria, Ion, Tratat de Teologie Dogmatică și Ecumenică/Treatise on Dogmatic and Ecumenical Theology, Editura România Creștină, București, 1999.

[6] Chircalan, Ionuț, Creator și creație. Părintele Dumitru Stăniloae - valorificator al scrierilor areopagitice/Creator and Creation. Father Dumitru Stăniloae - a Valuer of the Areopagitic Writings, Editura Universitară, București, 2021.

${ }^{38}$ Dumitru Popescu, Iisus Hristos Pantocrator, Editura Institutului Biblic și de Misiune al Bisericii Ortodoxe Române, București, 2005, p. 258. 
[7] Chițescu, Nicolae, Todoran, Isidor, Petreuță, I., Teologia Dogmatică și Simbolică/Dogmatic and Symbolical Theology, vol. II, Editura Institutului Biblic și de Misiune al Bisericii Ortodoxe Române, București, 1958.

[8] Citirigă, Vasile, Probleme fundamentale ale teologiei dogmatice și simbolice/Fundamental problems of dogmatic and symbolic theology, course notes, vol. II, Editura Ex Ponto, Constanța, 2001.

[9] Enache, Mihai, „Poziția Bisericii Ortodoxe în problema dialogului și a intercomuniunii în Biserica Romano-Catolică"/'"The position of the Orthodox Church in the issue of dialogue and intercommunication in the Roman Catholic Church", in Studii Teologice, 27/1-2 (1975).

[10] Evdokimov, Paul, Ortodoxia / Orthodoxy, translated Irineu Ioan Popa, Editura Institutului Biblic şi de Misiune al Bisericii Ortodoxe Române, 1996.

[11] Floca, Ioan N., Canoanele Bisericii Ortodoxe - texte și comentarii/ Canons of the Orthodox Church - texts and comments, f.e., Sibiu, 1992.

[12] Ichim, Dumitru, „Problema celibatului preoțesc în Biserica Romano-Catolică/ "The problem of priestly celibacy in the Roman Catholic Church", in Studii Teologice, 22/9-10 (1970).

[13] Joița, Alexandru, „Aspecte actuale în ecleziologia ortodoxă și cea romanocatolică"/"Current aspects in Orthodox and Roman Catholic ecclesiology", in Studii Teologice, 33/5-6 (1981).

[14] Klostermann, Ferdinand, "Rolul credincioșilor în Biserică după Conciliul al II-lea Vatican"/ "The role of the faithful in the Church after the Second Vatican Council", in Studii Teologice, 26/ 3-4 (1973).

[15] Meyendorff, John, Ortodoxie și catolicitate/ Orthodoxy and Catholicism,translated Călin Popescu, Editura Sophia, București, 2003.

[16] Pannenberg, W., „Riflessioni evangeliche sul servizio petrino del vescovo di Roma”" Evangelical reflections on the Petrine service of the bishop of Rome", in Anali di Scienze Religioase, 2 (1997).

[17] Popescu, Dumitru, Iisus Hristos Pantocrator/ Jesus Christ Pantocrator, Editura Institutului Biblic și de Misiune al Bisericii Ortodoxe Române, București, București, 2005.

[18] Popescu, Dumitru, Ortodoxie și contemporaneitate/ Orthodoxy and contemporaneity, Editura Institutului Biblic și de Misiune al Bisericii Ortodoxe Române, București, București, 1996.

[19] Popescu, Dumitru, „Sfânta Taină a Preoției - ierarhia sacramentală după Sfânta Scriptură și Sfânta Tradiție. Preoția obștească"/'The Holy Sacrament of the Priesthood - the sacramental hierarchy according to the Holy Scripture and the Holy Tradition. The public priesthood", in Ortodoxia, 1(1989).

[20] Popescu, Dumitru, Teologie și cultură/ Theology and culture, Editura Diogene, București, 1993.

[21] Preda, Constantin, „Tu es Petrus...”/,You are Petrus”: Matei 16, 17-19, in Studii Teologice, 1/2 (2005).

[22] Remete, George, Dogmatica Ortodoxă/ Orthodox dogmatics, manual pentru Seminariile Teologice, $3^{\text {rd }}$ edition, Editura Reîntregirea, Alba-Iulia, 2000.

[23] Stăniloae, Dumitru, Teologia Dogmatică Ortodoxă/ Orthodox Dogmatic Theology, vol. II, Editura Institutului Biblic și de Misiune al Bisericii Ortodoxe Române, București, București, 1978.

[24] Suciu, Vasile, Teologia Dogmatică fundamentală/ Fundamental Dogmatic Theology, vol. II, f.e., Blaj, 1927.

[25] Tucă, Nicușor, Valențe teologice in Liturghie și Sfintele Taine/ Theological Values in Liturgy and the Holy Sacraments, Editura Arhiepiscopiei Tomisului, Constanța, 2014. 